\title{
The use of social media in ethic digital perspective
}

\author{
Endrise Septina Rawanoko ${ }^{1}$, Kokom Komalasari ${ }^{2}$, Suwarma Al-Muchtar ${ }^{2}$, Prayoga Bestari ${ }^{2}$ \\ ${ }^{1}$ Program Studi PPKn, Universitas Wisnuwardhana, Malang, Indonesia \\ ${ }^{2}$ Departemen Pendidikan Kewarganegaraan, Universitas Pendidkan Indonesia, Bandung, Indonesia
}

\begin{abstract}
ABSTRAK
Penggunaan media sosial pada mahasiswa menjadi salah satu gaya hidup di lingkungan Universitas Wisnuwardhana Malang. Pada era digital seperti saat ini penggunaan media sosial sering disalahgunakan bahkan menjadi ajang bully, rasis, dsb. Untuk itu penggunaan media sosial perspektif digital ethic hadir sebagai cara untuk meminimalisir kebobrokan moral anak didik di media sosial. Riset ini berfokus pada penggunaan media sosial perspektif digital ethic pada mahasiswa di Universitas Wisnuwardhana Malang. Metode penelitian ini adalah kualitatif deskriptif. Hasil dari penelitian di lapangan mengenai penggunaan media sosial dan perspektif digital ethic adalah mayoritas mahasiswa Universitas Wisnuwardhana Malang menggunakan media hanya untuk memposting foto-foto pribadi serta kegiatan yang positif. Sistem komunikasi sosial yang ada di media sosial, sama persis dengan sistem komunikasi dalam lingkungan sehari-hari. Mahasiswa Universitas Wisnuwardhana Malang mempertimbangkan dalam mengupload ataupun memposting di media sosial.
\end{abstract}

\begin{abstract}
The use of social media for students is one of the lifestyles in the University of Wisnuwardhana Malang. In this digital era, the use of social media is often misused. It even becomes an arena for bullying, racism, etc. For this reason, the use of social media with an ethical digital perspective is present to minimize the moral decay of students on social media. This research focuses on using social media with a digital ethics perspective on students at Wisnuwardhana University Malang. This research method is descriptive qualitative. The research results in the field regarding the use of social media and the digital ethics perspective are that many Wisnuwardhana University Malang students use the media only to post personal photos and positive activities. The social communication system in social media is precisely the same as the communication system in everyday life. Wisnuwardhana University Malang students consider uploading or posting on social media
\end{abstract}

Article History:

Submitted : :11-04-2021

Revised : : 15-04-2021

Accepted : :17-04-2021

Keywords:

civic; digital; digital ethics; citizen

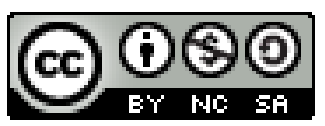

Cite in APA ${ }^{\text {7th: }}$

Rawanoko, E. S., Komalasari, K., Almuchtar, S., \& Bestari, P. (2021). The use of social media in ethic digital perspective. Jurnal Civics: Media Kajian Kewarganegaraan, 18(1), 148-157. https://doi.org/10.21831/jc.v18i1.4003

\section{Pendahuluan}

Pada era keterbukaan dewasa ini peran media sosial semakin memonopoli kehidupan manusia, semuanya menjadi satu yaitu warga negara global melalui media sosial. Sebagian besar kehidupan manusia bergantung pada media sosial. Tujuan utama dari media sosial adalah sebagai sarana komunikasi untuk menghubungkan antar pengguna dengan cakupan wilayah seluruh dunia. Banyaknya media online dan media sosial yang menawarkan berbagai akses kemudahan akan lebih efektif dan bermanfaat bila dijadikan sebagai wadah dalam memberikan masukan, kritik 
maupun saran dalam pembangunan. Di sisi lain perlu adanya dorongan kepada semua lapisan masyarakat agar memiliki etika bagaimana memanfaatkan media sosial.

Media sosial adalah salah satu platform komunikasi yang berkembang paling dinamis. Itu telah mengalami banyak perubahan signifikan, berkembang dari kecil, tersebar, situs komunitas lokal, menjadi perusahaan terkonsolidasi dengan jangkauan global. Media sosial juga telah mengalami lompatan ke dalam teknologi seluler, yang memiliki pengaruh luar biasa terhadap perilaku manusia, termasuk pola penggunaan media sosial. Terakhir, namun tak kalah pentingnya, dari waktu ke waktu, motivasi pengguna untuk berpartisipasi dalam diskusi di media sosial juga berubah. Motivasi murni "sosial" telah berangsur-angsur digantikan oleh motivasi lain, seperti pencarian informasi, yang telah menempatkan platform sosial lebih dekat dengan media tradisional (Bialy, 2017).

Media sosial adalah hal yang populer sehingga hamper dipastikan setiap orang selalu membuka media sosial. Setiap manusia terhubung dengan media sosial baik di Linkedln, menerima permintaan pertemanan di Facebook, atau mendengar tentang Twitter di TV. Apa itu media sosial? Wikipedia yang serba tahu mendefinisikan media sosial sebagai "alat berbasis internet untuk berbagi dan mendiskusikan informasi di antara manusia". Itu bukan definisi yang buruk. Kami akan menyederhanakannya dan mengatakan bahwa media sosial adalah tentang orang-orang yang berhubungan, berinteraksi, dan berbagi secara online. Mengapa Anda harus peduli dengan media sosial? Jawabannya adalah sama seperti mengapa Anda harus peduli tentang Google karena Google menyediakan cara yang bagus untuk menjangkau dan melibatkan calon pelanggan. Seperti halnya dengan Google, lebih banyak calon pelanggan Anda yang nongkrong di media sosial, jadi di sinilah Anda juga perlu nongkrong, jika Anda ingin terlibat dengan mereka (Hussain, 2014).

Media sosial adalah tentang orang yang mempengaruhi orang lain dalam situasi sosial melalui teknologi. Komputer sebagai media yang memfasilitasi, tetapi media sosial adalah tentang apa yang dilakukan orang untuk memengaruhi orang lain setidaknya sebanyak teknologi yang mereka gunakan untuk melakukan hal-hal itu. Istilah "jejaring sosial" tentu saja merupakan bagian dari apa yang diproduksi sebagai media sosial, tetapi tidak mencakup semua bentuk media sosial. Karena semakin banyak produk penerbitan menawarkan fungsi yang memungkinkan orang untuk tetap berhubungan satu sama lain dan melakukan percakapan. Media sosial menggunakan teknologi yang sangat scalable dan mudah diakses (Blossom, 2009).

Kehadiran media sosial di kalangan remaja, membuat ruang privat seseorang melebur dengan ruang publik. Terjadi pergeseran budaya di kalangan remaja, para remaja tidak segansegan mengunggah segala kegiatan pribadinya untuk disampaikan kepada teman-temannya melalui akun media sosial dalam membentuk identitas diri mereka. Konvergensi media menghasilkan perubahan dalam arus informasi. Konvergensi media merupakan sebuah istilah yang mulai banyak digunakan sejak tahun 1990-an. Konvergensi menjadi suatu istilah yang umum dipakai dalam perkembangan teknologi digital, dimana di dalam konvergensi mengintegrasikan teks, angka, gambar, video, dan suara dalam suatu media (Ayun, 2015).

Dalam media sosial, konten yang bersifat pribadi dapat menjadi milik publik. Setiap individu pengguna media sosial seharusnya memiliki kesadaran pribadi, bahwa apapun yang diunggah ke dalam media sosial selain dapat mempengaruhi citra diri sendiri, juga dapat mempengaruhi hubungan sosial dengan pihak lain. Keluasan informasi hendaklah dipilah dengan bijaksana, mana saja yang dapat digunakan dengan baik tanpa melanggar norma dan nilai-nilai yang berlaku dalam kehidupan sosial. Kebebasan berekspresi harus tetap berpegang pada etika komunikasi dan pengendalian diri yang baik (Anwar, 2017). 
Netizen di Indonesia sebagian besar belum mengindahkan etika komunikasi dalam mengkonsumsi media sosial Instagram. Etika berkomunikasi dalam implementasinya antara lain dapat diketahui dari komunikasi yang santun. Netizen akan memberikan pujian yang berlebihan pada sesuatu yang mereka sukai, akan tetapi akan memberikan umpatan yang kasar pada akun yang tidak mereka sukai. Bahkan tidak jarang terjadi perundungan pada sesuatu yang buruk dan sedang viral, misalnya terjadi tindak kekerasan pada seorang guru yang akhir-akhir ini terjadi. Para netizen otomatis akan mencari tau akun dari pelaku kekerasan dan kompak untuk melakukan umpatan dengan nada kasar. Akan tetapi sebaliknya, bila terdapat informasi viral yang bagus mereka akan memberikan pujian dengan berlebihan terkadang seperti kita tenggelam ke dalam dunia maya. Etika berkomunikasi, tidak hanya berkaitan dengan tutur kata yang baik, tetapi juga harus berangkat dari niat tulus yang diekspresikan dari ketenangan, kesabaran dan empati kita dalam berkomunikasi. Bentuk komunikasi yang demikian akan menghasilkan komunikasi dua arah yang bercirikan penghargaan, perhatian dan dukungan secara timbal balik dari pihak-pihak yang berkomunikasi (Sandra \& Dewi, 2019).

Etika di ruang siber (netiquette) berbeda dari bentuk etika lainnya, sama seperti aturan etika di dunia nyata, netiquette juga mendorong para pengguna untuk taat pada aturan etis dan moral untuk menciptakan ruang bersama yang nyaman, tenteram, dan damai. Kecerdasan bermedia sosial memungkinkan kita untuk tidak menciptakan resistensi yang semakin runcing dengan lingkungan sekitar. Sistem komunikasi sosial yang ada di media sosial, sama persis dengan sistem komunikasi dalam lingkungan sehari-hari. Oleh karenanya, tata krama dan sopan santun serta nilai-nilai etis lainnya perlu dijunjung tinggi. Meskipun disadari pula, perilaku non-etis di internet dan media sosial sangat sulit dikendalikan karena setiap orang bisa memiliki lebih dari satu akun dengan foto yang dapat dipaksakan. Namun, setidaknya pemahaman netiquette menjadi panduan bagi generasi millennial untuk lebih literate internet (Fahrimal, 2018).

Temuan penelitian mengenai dampak media sosial membawa perubahan-perubahan dalam hubungan sosial (social relationships) atau sebagai perubahan terhadap keseimbangan (equilibrium) hubungan sosial dan segala bentuk perubahan-perubahan pada lembaga-lembaga kemasyarakatan di dalam suatu masyarakat, yang mempengaruhi sistem sosialnya, termasuk di dalamnya nilai-nilai, sikap dan pola perilaku diantara kelompok-kelompok dalam masyarakat. Perubahan sosial yang cenderung negatif seperti munculnya kelompok-kelompok sosial yang mengatasnamakan agama, suku dan pola perilaku tertentu yang terkadang menyimpang dari norma-norma yang ada (Cahyono, 2016).

Dalam penelitian Ayun (2015) yang membahas fenomena remaja menggunakan media sosial dalam membentuk identitas menghasilkan penelitian berupa; (1) remaja menunjukkan identitas diri yang berbeda-beda dalam ketiga akun media sosial tersebut; (2) secara orientasi personal, para remaja menggunakan media sosial dikarenakan mereka ingin menjalin komunikasi dengan teman-teman mereka. sehingga mereka memutuskan untuk memiliki akun media sosial lebih dari satu; (3) nilai individu yang ditampilkan dalam media sosial, para remaja mencoba membuat sebuah citra positif tentang diri mereka di media sosial tersebut. remaja suka menampilkan identitas mereka yang smart, terlihat bahagia, dan suka menampilkan hobi atau kegiatan yang mereka sukai; (4) para remaja cukup terbuka di media sosial dalam menunjukkan identitas mereka. hal ini ditunjukkan dengan keterbukaan diri mereka melalui keinginan mereka untuk tetap diakui dengan mengunggah kegiatan yang sedang mereka lakukan (baik melalui foto ataupun status) dan mengungkapkan permasalahan pribadi di media sosial, dalam bentuk tersirat.

Pada penelitian Beata Bialy mengenai media sosial pengamatan media sosial merumuskan beberapa rekomendasi kunci; (1) hadir di media sosial dengan konten yang menarik dan 
disesuaikan dengan baik; (2) gunakan apa yang ditawarkan teknologi; (3) tingkatkan narasi anda sendiri dan kembangkan branding yang menarik; (4) sangat penting untuk meningkatkan kesadaran akan aktivitas pengaruh yang digunakan oleh lawan kita. ada dua garis pertahanan utama: pendidikan dan pemaparan aktivitas yang tidak bersahabat; (5) pendidikan memberi warga (mulai dari usia yang relatif muda) pengetahuan dasar tentang media dan media sosial yang membantu membangun pemikiran kritis dan kebiasaan memeriksa fakta; (6) pengungkapan aktivitas bermusuhan membutuhkan pelacakan penipuan online, manipulasi dan disinformasi, dan menetralkan dengan kebenaran. karena betapapun mulianya kedengarannya, kebenaran adalah senjata yang ampuh (Bialy, 2017).

Dari sudut pandang respons terhadap masyarakat sipil, sebelum munculnya media massa di Tiongkok pada abad ke-20, ada etos di mana seorang kaisar yang baik hati dan lapisan mandarin yang meritocratic harus membimbing moral masyarakat dan mengatur kesejahteraan mereka. Tradisi ini berlanjut di bawah komunisme, dengan rezim yang mengerahkan penduduk untuk memajukan bangsa. Sistem media menjadi semakin sentral dalam pedoman penduduk ini, dan tradisi tersebut terus berlanjut hingga era reformasi pro pasar. Upaya saat ini untuk mengukur sentimen publik melalui media sosial dapat dilihat sebagai perpanjangan dari proses ini, seperti penggunaan media untuk mempromosikan stabilitas sosial dan mempromosikan ekonomi teknologi tinggi. Sisi sebaliknya dari ini adalah penghapusan ketidakpuasan dan ketidakteraturan. Rezim melihat media sebagai ancaman, terutama di tengah runtuhnya Uni Soviet dan protes di Lapangan Tiananmen. Pertanyaannya kemudian adalah sejauh mana tujuan rezim telah mengalami ketegangan dengan komersialisasi media baru-baru ini dan meluasnya penggunaan media sosial. Perlu juga dicatat bagaimana media digital telah mengubah masalah ini: untuk media penyiaran, para jurnalis lah yang melakukan swasensor, dan hal itu diketahui dengan baik. Dalam dunia online, kita dapat membedakan antara para pemimpin opini (pebisnis terkenal, selebriti budaya dan sejenisnya, yang sangat populer di media sosial China) dan aktivis akar rumput. Untuk kedua kelompok, swasensor tidak (atau kurang) terkait dengan kehilangan posisi mereka karena kontrol partai, tetapi lebih merupakan sensor yang diberlakukan sendiri karena takut akan pembalasan (Schroeder, 2018).

Pada penelitian yang dilakukan di Surakarta tentang penguatan etika digital pada siswa ditemukan hambatan dalam penguatan etika digital pada siswa untuk menanggulangi penyebaran berita bohong (melalui Pendidikan Kewarganegaraan di SMA/SMK Kota Surakarta adalah faktor dari peserta didik. Beberapa faktor antara lain; (1) latar belakang atau status sosial yang berbedabeda mempengaruhi etika digital setiap siswa, hal ini berkaitan dengan hak dan akses digital yang tidak sama rata; (2) tingkat kemampuan siswa dalam menyerap informasi formasi berbeda-beda sehingga menimbulkan ketidakmampuan siswa dalam menanggapi apa yang diarahkan oleh guru itu sendiri; (3) minimnya kemampuan guru Pendidikan Kewarganegaraan dalam menggunakan media digital, sehingga guru kalah canggih dengan siswa. Akibat dari hal tersebut guru tidak dapat mengontrol aktivitas siswa dalam hal menggunakan media digital dalam proses pembelajaran; (4) lingkungan, yaitu berkaitan dengan masa-masa pemilu yang akan diselenggarakan dalam waktu dekat, mau tidak mau penyebaran berita bohong marak terjadi untuk menyerang politik (Pramanda et al., 2018).

Studi di Australia menghadirkan media berita di daerah dengan tantangan khusus. Mereka mungkin telah diisolasi sampai batas tertentu oleh hubungan lama mereka dengan sebagian besar terikat secara geografis, tetapi karena pemahaman tentang jaringan dan keterlibatan ruang publik berubah, dan pemahaman tentang pergeseran tempat, mereka berisiko tertinggal. Meskipun studi yang dilaporkan di atas memiliki keterbatasan karena hanya meneliti keluaran media sosial yang diterbitkan dari surat kabar, daripada mempertimbangkan motivasi jurnalis atau tanggapan langsung dari khalayak, namun tetap merupakan langkah pertama dalam memberikan petunjuk 
tentang bagaimana surat kabar regional Australia berada. memanfaatkan media sosial dan apakah pemanfaatan tersebut menempatkan mereka dalam posisi untuk memperluas publik mereka. Ini menunjukkan bahwa sebagian besar praktik komunikasi yang sudah mapan direplikasi melalui media sosial, ditambah dengan perhatian terbatas pada cara baru untuk mendongeng dan panggilan dangkal untuk interaksi. Akibatnya, alih-alih mampu memperluas publik mereka ketika hambatan geografis dan komunikasi lainnya runtuh, dan dengan demikian mengonsolidasikan tempat mereka sebagai elemen sentral jaringan komunikasi lokal, outlet berita berisiko memecahbelah warga net yang ada di berbagai platform di mana warga net ini semakin terlibat (Bowd, 2013).

Pertanyaan yang diajukan dalam penelitian ini adalah bagaimana mahasiswa menggunakan media sosial dalam perspektif digital ethic. Agar penelitian lebih terfokus, peneliti membagi topik tersebut ke dalam dua sub masalah, yaitu tentang bagaimana peran media sosial dalam kehidupan mahasiswa dan bagaimana perilaku mahasiswa di media sosial jika ditinjau dari perspektif digital ethic.

\section{Metode}

Penelitian ini menggunakan pendekatan kualitatif. Pendekatan penelitian kualitatif adalah penelitian yang berlandaskan filsafat positivisme, digunakan untuk meneliti pada kondisi objek yang alamiah, dimana peneliti adalah sebagai instrumen kunci (Creswell, 2015). Peneliti sebagai instrumen kunci, dalam setting yang alamiah para peneliti kualitatif melakukan interaksi face to face sepanjang penelitian (Creswell, 2015). Pendekatan kualitatif adalah riset yang bersifat deskriptif dan cenderung menggunakan analisis untuk mempermudah mendapatkan penjelasan dan gambaran tentang penggunaan media sosial dan perspektif digital ethic.

Penelitian ini dilakukan di Kota Malang dengan subjek penelitian adalah mahasiswa Universitas Wisnuwardhana Malang sebanyak 10 orang yang dipilih secara acak setiap fakultas yang ada di Universitas Wisnuwardhana Malang. Teknik pengumpulan data dalam penelitian ini menggunakan wawancara terhadap pengguna media sosial serta pengamatan terhadap pengguna media sosial yang memuat konten protes sosial, umpatan, bullying, dan pornografi. Pengumpulan data lainnya melalui dokumentasi artikel hasil penelitian, buku, maupun jurnal yang membahas media sosial dan digital ethic. Wawancara dilakukan secara terstruktur dengan menggunakan pedoman pertanyaan wawancara meliputi penggunaan media sosial. Wawancara berlangsung selama 30-40 menit untuk mendapatkan data yang sesuai dengan tujuan wawancara, peneliti membawa alat tulis dan alat rekam selama wawancara berlangsung.

Penelitian ini menggunakan teknik analisis data yang dikemukakan yang meliputi tiga kegiatan yaitu: (1) reduksi data artinya merangkum, memilih hal-hal yang pokok, memfokuskan pada hal-hal yang penting. dengan demikian data yang telah direduksi akan memberikan gambaran yang lebih jelas dan mempermudah peneliti untuk melakukan pengumpulan data selanjutnya; (2) setelah data direduksi maka langkah selanjutnya adalah penyajian data.

Triangulasi adalah proses menggunakan beberapa metode, strategi pengumpulan data, dan sumber data untuk mendapatkan gambaran yang lebih lengkap tentang apa yang dipelajari dan untuk memeriksa informasi. Kekuatan penelitian kualitatif terletak pada pengumpulan informasi dalam banyak cara, bukan hanya mengandalkan satu, dan seringkali dua atau lebih metode dapat digunakan sedemikian rupa sehingga kekuatan satu mengompensasi kelemahan yang lain, Gay et al (2012, hlm. 393). 


\section{Hasil dan Pembahasan}

Berdasarkan rumusan masalah penelitian, maka penelitian ini melihat bagaimana peran media sosial dalam kehidupan mahasiswa dan bagaimana perilaku mahasiswa di media sosial jika ditinjau dari perspektif digital ethic. Guna menjaga kerahasiaan dan etika penelitian maka narasumber dalam penelitian akan disebutkan inisial saja. Diskusi dibagi ke dalam dua hal pembahasan sesuai dengan 2 rumusan permasalahan dalam penelitian.

\section{Peran Media Sosial dalam Kehidupan Mahasiswa}

Media sosial bagi masyarakat kini bukan hanya sebagai pengganti proses komunikasi secara langsung saja, akan tetapi dengan media sosial masyarakat lebih dimudahkan baik dalam proses komunikasi maupun informasi. Adanya kemajuan teknologi berdampak pada terjadinya gejala penurunan etika dalam berkomunikasi. Penurunan etika yang terjadi akibat penggunaan media sosial dapat diantisipasi melalui pengawasan yang dilakukan oleh lembaga pendidikan. Warga negara digital harus memiliki keterampilan, pengetahuan, akses internet dan teknologi yang bertanggung jawab.

Hasil wawancara pada mahasiswa dari Prodi Pendidikan Pancasila dan Kewarganegaraan menyatakan bahwa fungsi media sosial adalah salah satu sarana mengekspresikan diri.

Pewawancara: Apakah anda menggunakan media sosial dalam aktivitas dan kehidupan sehari-hari?

AYK: "Ya, saya menggunakan media sosial dalam kehidupan sehari-hari saya. Saya aktif di media sosial Facebook dan Instagram, saya hanya mengunggah foto dan sedikit kata-kata motivasi untuk saya dan teman-teman di media sosial yang saya miliki.

Sementara itu MLJD menanggapi "Saya juga menggunakan media sosial Facebook dan Instagram hanya untuk memposting foto dan kata-kata motivasi juga firman Tuhan."

DN menambahkan "Saya menggunakan media sosial Facebook dan Instagram yang saya miliki untuk kegiatan saya sehari-hari, saya membagikan kegiatan saya ketika di kampus dan menjalankan organisasi MENWA yang saya ikuti di Universitas Wisnuwardhana Malang."

Berdasarkan hasil wawancara tersebut dapat disimpulkan bahwa mahasiswa Universitas Wisnuwardhana Malang menggunakan media hanya untuk memposting foto-foto pribadi serta kegiatan yang positif. Berdasarkan temuan lapangan melalui observasi dalam penggunaan media sosial melalui akun Facebook dan Instagram beberapa mahasiswa Universitas Wisnuwardhana Malang hanya mengunggah foto-foto pribadi dengan pakaian yang sopan dan yang berisikan kegiatan sehari-hari di lingkungan tempat tinggal maupun kegiatan di kampus beserta kata-kata mutiara, firman Tuhan sesuai dengan agamanya. Hal ini dapat disimpulkan bahwa mahasiswa Universitas Wisnuwardhana Malang telah menggunakan media sosialnya baik di Instagram maupun Facebook dengan baik dan bijak karena tidak ada satu pun unggahan mengenai hal negatif, baik itu rasis, perundungan, maupun pornografi.

\section{Perilaku Mahasiswa Di Media Sosial dalam Perspektif Digital Ethic}

Sama seperti aturan etika di dunia nyata, netiquette juga mendorong para pengguna untuk taat pada aturan etis dan moral yang meskipun tidak tertulis untuk menciptakan ruang bersama yang nyaman, tenteram, dan damai. Namun, aturan-aturan ini terkadang sengaja diabaikan khususnya oleh generasi millennial. Mereka merasa ingin bebas dan menjadikan ruang siber sebagai ruang privasi -alih-alih ruang publik (Fahrimal, 2018).

Hasil wawancara pada mahasiswa dari Universitas Wisnuwardhana Malang menyatakan bahwa perilaku mahasiswa di media sosial bernilai positif dalam perspektif digital ethic. 
Pewawancara: Apakah anda pernah mengunggah konten media sosial yang mengandung umpatan atau kata-kata sumpah serapah ketika anda tidak berkenan terhadap segala sesuatunya? dalam aktivitas dan kehidupan sehari-hari?

MNH: "Tidak pernah, saya menggunakan media sosial saya baik Facebook dan Instagram hanya memposting foto saya, teman, dan keluarga saya."

DW menambahkan "Saya rasa tidak etis ketika mengungkapkan keresahan di media sosial karena dapat menimbulkan banyak komentar entah itu komentar yang baik maupun yang dapat menjatuhkan.

OSI menambahkan "Saya juga hanya mengunggah foto-foto pribadi saya dan jarang berkomentar di media sosial"

Berdasarkan hasil wawancara tersebut dapat disimpulkan bahwa mahasiswa Universitas Wisnuwardhana Malang menggunakan media hanya untuk memposting foto-foto pribadi serta kegiatan yang positif. Sistem komunikasi sosial yang ada di media sosial, sama persis dengan sistem komunikasi dalam lingkungan sehari-hari. Oleh karenanya, tata krama dan sopan santun serta nilai-nilai etis lainnya perlu dijunjung tinggi. Meskipun disadari pula, perilaku non-etis di internet dan media sosial sangat sulit dikendalikan karena setiap orang bisa memiliki lebih dari satu akun dengan avatar-avatar yang dapat dipalsukan. Namun, setidaknya pemahaman netiquette menjadi panduan bagi generasi millennial untuk lebih literate internet (Fahrimal, 2018). Dengan demikian pemanfaatan media sosial bagi mahasiswa di Universitas Wisnuwardhana Malang dilakukan dengan cara positif karena mahasiswa tidak adanya konten media sosial yang mengandung rasis terhadap etnis atau agama tertentu, tidak adanya konten media sosial yang mengandung curah perasaan berdasarkan realitas yang telah dan sedang terjadi, tidak adanya konten media sosial yang mengandung umpatan atau kata-kata sumpah serapah, tidak adanya konten media sosial yang mengandung bullying terhadap individu tertentu, tidak adanya konten media sosial yang mengandung unsur pornografi.

Berdasarkan temuan lapangan melalui observasi dalam penggunaan media sosial, mahasiswa Universitas Wisnuwardhana Malang mempertimbangkan dalam mengunggah ataupun memposting di media sosial. Oleh karena itu pada temuan observasi pada media sosial yang dimiliki mahasiswa Wisnuwardhana Malang tidak ditemukan konten media sosial yang mengandung rasis terhadap etnis atau agama tertentu, tidak ditemukan adanya konten media sosial yang mengandung curah perasaan berdasarkan realitas yang telah dan sedang terjadi, tidak ditemukan adanya konten media sosial yang mengandung umpatan atau kata-kata sumpah serapah, tidak ditemukan adanya konten media sosial yang mengandung bullying terhadap individu tertentu, tidak ditemukan adanya konten media sosial yang mengandung unsur pornografi. Hal ini dapat disimpulkan melalui observasi yang dilakukan oleh peneliti bahwa mahasiswa Universitas Wisnuwardhana Malang sangat menjaga etika dalam berkomunikasi dalam hal ini digital ethic.

Media, dalam kajian politik modern, dianggap sebagai salah satu tiang dari demokrasi. Oleh sebab itu, keterlibatannya dalam dunia politik sudah seharusnya memberikan peran yang membangun dunia yang lebih baik. Peran yang dibangun tidak lain adalah partisipasi politik warga negara. Partisipasi dalam sistem tata kelola, sejak lama telah dipandang sebagai tonggak demokrasi Namun demikian, media seringkali dijadikan alat hegemoni politik penguasa. Aminah mengutarakan "media menjadi perpanjangan tangan kepentingan penguasa, bahasa politik bermakna ganda untuk tujuan penghalusan maupun untuk kepentingan memperdayakan 
warganegara, keduanya adalah bagian dari politik hegemoni sebagai syarat untuk mengukuhkan kuasa penguasa (Aminah, 2006).

Pola partisipasi politik warga negara mengalami perubahan seiring penggunaan media (Bennett, 2008). Pola partisipasi politik warga negara dan media setidaknya dapat dirumuskan pada empat dimensi, yakni patuh, opsional, individu dan kolektif (Ohme, 2018). Warga negara yang patuh merasa wajib untuk tetap mendapat informasi tentang perkembangan politik, menganggap organisasi politik penting dan menganggap pemungutan suara sebagai tugas kewarganegaraan paling penting (Bennett, 2008; Mascheroni, 2015; Moeller et al., 2018). Pengalaman opsional memberikan peluang lebih dari sekadar kepatuhan untuk berpartisipasi yang memungkinkan warga negara mengurangi partisipasi politiknya akibat pilihan-pilihan itu (Ohme, 2018). Akibat dari pilihan partisipasi itu, maka individu memiliki kemandirian untuk menentukan pilihan partisipasi dan aktualisasi diri dengan keyakinan kuat pada kemampuan individu untuk mencapai perubahan di masyarakat (Mascheroni, 2015). Pada akhirnya, ada kesadaran kolektif lebih dari sekadar "aku" menjadi "kita" untuk menciptakan perubahan masyarakat (Mascheroni, 2015; Ohme, 2018). Terlebih lagi, masyarakat yang sungguh demokratis bersandar pada masyarakat sadar informasi yang mampu membuat pilihan-pilihan politis sehingga akses terhadap informasi tidak hanya menjadi hak dasar warga, tetapi juga sebuah prasyarat dari demokrasi itu sendiri (Joseph, 2005).

Dalam konteks kewarganegaraan dan hubungannya dengan media, terdapat istilah kewarganegaraan digital. Kewarganegaraan memandang bahwa media memegang peranan penting. Kewarganegaraan digital dapat didefinisikan sebagai norma-norma perilaku dengan memperhatikan untuk penggunaan teknologi. Lebih singkat dikatakan bahwa kewarganegaraan digital sebagai kemampuan untuk berpartisipasi dalam masyarakat online (Mossberger et al., 2008). Kewarganegaraan digital juga diartikan kemampuan untuk menggunakan teknologi secara kompeten; menafsirkan dan memahami konten digital dan menilai kredibilitasnya; membuat, meneliti, dan berkomunikasi dengan alat yang tepat; berpikir kritis tentang peluang dan tantangan etika dunia digital; membuat pilihan online yang aman, bertanggung jawab, dan penuh hormat (Isman \& Canan Gungoren, 2014). Dengan demikian, kata kunci dari beberapa definisi di atas adalah adanya meliputi pengetahuan dan keterampilan untuk menggunakan teknologi secara tepat dalam dunia digital, mengelola risiko dan memanfaatkan peluang partisipatif yang ditawarkannya (Partnership for 21st Century Skills, 2014) Sementara itu warga negara digital mereka yang menggunakan Internet secara teratur dan efektif setiap hari (Mossberger et al., 2008). Apa yang menjadi harapan media sebenarnya adalah pencerdasan warga negara dalam alam demokrasi dengan partisipasi aktif dan positif warga negara untuk turut serta dalam kehidupan demokrasi yang berketuhanan, berkemanusiaan, merangkul persatuan, dan berkeadilan sosial.

Dengan demikian, media berada di ruang publik sehingga semua orang bisa mengaksesnya. Habermas (1984) mensyaratkan "komunikasi yang tidak terdistorsi" dalam demokrasi yang berada pada ranah publik di mana individu-individu dalam masyarakat saling berinteraksi dan menciptakan demokrasi yang berkesadaran. Mengenai hubungan penggunaan media berita di internet, Hasil penelitian Reichert \& Print (2017) menemukan bahwa penggunaan media berita merangsang diskusi tentang isu-isu kewarganegaraan, meskipun media yang berbeda memberikan efek yang berbeda, dengan mendengarkan berita di radio sama sekali tidak relevan dalam mempromosikan diskusi tersebut. Paparan berita jarang menghasilkan efek positif pada pengetahuan dan efikasi masyarakat. Seperti yang diharapkan, pengetahuan kewarganegaraan juga meningkatkan efikasi kewarganegaraan, tetapi pengaruh langsung pada partisipasi politik yang dimaksudkan tidak konsisten, karena ada efek positif dan negatif, tergantung pada jenis kegiatan (Reichert \& Print, 2017). Namun, efikasi masyarakat adalah perintis/pendahulu partisipasi 
yang cukup kuat. Selain itu, penelitiannya memeriksa efek tidak langsung dan mengonfirmasi bahwa pengetahuan dan efikasi politik memediasi hubungan antara komunikasi sipil dan partisipasi, baik secara langsung dan berurutan. Alih-alih, dan meskipun peran mediasi dalam diskusi kewarganegaraan, paparan media berita (surat kabar, radio, dan Internet) juga memengaruhi partisipasi warga negara yang bergantung pada keterlibatan siswa dalam diskusi (terutama berbasis Internet) tentang masalah kewarganegaraan.

\section{Simpulan}

Pertama, media sosial adalah salah satu platform komunikasi yang berkembang paling dinamis. Itu telah mengalami banyak perubahan signifikan, berkembang dari kecil, tersebar, situs komunitas lokal, menjadi perusahaan terkonsolidasi dengan jangkauan global. Media sosial juga telah mengalami lompatan ke dalam teknologi seluler, yang memiliki pengaruh luar biasa terhadap perilaku manusia, termasuk pola penggunaan media sosial. Kehadiran media sosial di kalangan remaja, membuat ruang privat seseorang melebur dengan ruang publik.

Kedua, hasil dari penelitian di lapangan mengenai penggunaan media sosial dan perspektif digital ethic melalui hasil wawancara, mayoritas mahasiswa Universitas Wisnuwardhana Malang menggunakan media hanya untuk memposting foto-foto pribadi serta kegiatan yang positif. Sistem komunikasi sosial yang ada di media sosial, sama persis dengan sistem komunikasi dalam lingkungan sehari-hari. Dengan demikian pemanfaatan media sosial bagi mahasiswa di Universitas Wisnuwardhana Malang dilakukan dengan cara positif.

Ketiga, berdasarkan temuan lapangan melalui observasi dalam penggunaan media sosial, mahasiswa Universitas Wisnuwardhana Malang mempertimbangkan dalam mengunggah ataupun memposting di media sosial. Oleh karena itu pada temuan observasi di media sosial yang dimiliki oleh Mahasiswa Universitas Wisnuwardhana Malang tidak ada konten yang mengarah ke arah rasis, umpatan, ujaran kebencian, hoax, juga pornografi. Hal ini dapat disimpulkan bahwa mahasiswa Universitas Wisnuwardhana Malang sangat menjaga etika dalam berkomunikasi dalam hal ini digital etik.

\section{Referensi}

Aminah, S. (2006). Politik media, demokrasi dan media politik. Masyarakat, Kebudayaan dan Politik, 19(3), 35-46.

Anwar, F. (2017). Perubahan dan permasalahan media sosial. Jurnal Muara Ilmu Sosial, Humaniora, dan Seni, 1(1), 137-144. https://doi.org/10.24912/jmishumsen.v1i1.343

Ayun, P. Q. (2015). Fenomena remaja menggunakan media sosial dalam membentuk identitas. Channer: Jurnal Komunikasi, 3(2), 1-16. https://doi.org/10.12928/channel.v3i2.3270

Bennett, W. L. (2008). Changing citizenship in the digital age. In W. L. Bennett (Ed.), Civic life online: Learning how digital media can engage youth (hal. 1-24). The MIT Press. https://doi.org/10.1162/dmal.9780262524827.001

Bialy, B. (2017). Social media-from social exchange to battlefield. The Cyber Defense Review, 2(2), 69-90. http://www.jstor.org/stable/26267344

Blossom, J. (2009). Content nation: surviving and thriving as social media changes our work, our lives, and our future. Wiley Publishing, Inc.

Bowd, K. (2013). Social media and news media: Building new publics or fragmenting audiences. Africa's potential for the ecological intensification of agriculture, 53(9), 1689-1699. 
Cahyono, A. S. (2016). Pengaruh media sosial terhadap perubahan sosial masyarakat di Indonesia. Jurnal PUBLICIANA, 9(1), https://journal.unita.ac.id/index.php/publiciana/article/view/79

Creswell, J. (2015). Riset pendidikan perencanaan, pelaksanaan, dan evaluasi riset kualitatif dan kuantitatif. (Edisi Keli). Pustaka Pelajar.

Fahrimal, Y. (2018). Netiquette: Etika jejaring sosial generasi milenial dalam media sosial. Jurnal Penelitian Pers dan Komunikasi Pembangunan, 22(1), 69-78. https://doi.org/10.46426/jp2kp.v22i1.82

Gay, R. L., Mills, G. E., \& Arasian, P. (2012). Educational research competencher for analysis and applications (Tenth Edit). Person Education.

Habermas, J. (1984). The theory of communicative action. Vol. I: Reason and the rationalization of society. Beacon.

Hussain, N. (2010). A little empathy goes along way: How brands can engage he American muslim consumer. Ogilvy \& Mather.

Isman, A., \& Canan Gungoren, O. (2014). Digital citizenship. Turkish Online Journal of Educational Technology, 13(1), 73-77. https://doi.org/10.4324/9781315622408-9

Joseph, A. (2005). Media matter, citizens care: the who, what, when, where, why, how, and buts of citizens' engagement with the media. Unesco.

Mascheroni, G. (2015). The practice of participation. Youth's vocaularies around on-and offline civic and political engagement (No. 35; Nomor 35).

Moeller, J., Kühne, R., \& De Vreese, C. (2018). Mobilizing youth in the 21st century: How digital media use fosters civic duty, information efficacy, and political participation. Journal of Broadcasting \& Electronic Media, 62(3), 445-460. https://doi.org/10.1080/08838151.2018.1451866

Mossberger, K., Tolbert, C. J., \& McNeal, R. S. (2008). Digital citizenship. The internet, society, and participation. The MIT Press.

Ohme, J. (2018). Updating citizenship? The effects of digital media use on citizenship understanding and political participation. Information Communication and Society, $\mathrm{O}(0), 1-$ 26. https://doi.org/10.1080/1369118X.2018.1469657

Partnership for 21st Century Skills. (2014). Reimagining citizenship for the 21st century: a call to action for policymakers and educators.

Pramanda, A. Y., Muchtarom, M., \& Hartanto, R. V. P. (2018). Penguatan Etika Digital Pada Siswa Untuk Menanggulangi Penyebaran Berita Bohong (hoax) di Media Sosial Melalui Pendidikan Kewarganegaraan. 21(2). https://doi.org/10.20961/paedagogia.v21i2.23922

Reichert, F., \& Print, M. (2017). Mediated and moderated effects of political communication on civic participation. Information, Communication \& Society, 20(8), 1162-1184.

Sandra, M., \& Dewi, R. (2019). Islam dan etika bermedia (Kajian etika komunikasi netizen di media sosial Instagram dalam perspektif islam ). Research Fair Unisri, 3(1), 139-142. https://doi.org/10.33061/rsfu.v3i1.2574

Schroeder, R. (2018). Media systems, digital media and politics. In Social Theory after the Internet (hal. 1-33). https://doi.org/10.2307/j.ctt20krxdr.5 